\title{
Financial Performance of Non-oil Manufacturing Companies Listed on the Libyan Stock Market (LSM): Mixed Methods Study
}

\author{
Khalifa Mohamed Khalifa Omar \\ Lecturer, Department of Accounting \\ Higher Institute of Science and Technology, Zintan, Libya \\ E-mail: yahrap22@yahoo.com
}

Received: September 22, 2019

Accepted: October 18, 2019 Published: October 29, 2019

doi:10.5296/ijafr.v9i4.15730

URL: https://doi.org/10.5296/ijafr.v9i4.15730

\begin{abstract}
The major objective of this study is to assess the financial performance and identify the affecting factors in this performance of non-oil manufacturing companies from 1999 to 2008. The study sample consisted of all non-oil manufacturing companies' enlisted at Libyan stock market which count (8). The data collected was analyzed by using statistical analysis method such as descriptive statistics, correlation test, Multiple- regression, as well as semi-structured interviews method. The results regarding to the statistical analysis method (net working capital, inventory turnover ratio, selling and general administrative expenses ratio, and company size and company age), have a positive statistical effect on the financial performance(ROA), while the variables of (current ratio, quick ratio and account receivable turnover ratio), have a negative statistical effect on the financial performance (ROA). The results regarding to semi-structured interviews method, reveal that the respondents in the interviews were confirmed that the selected factors have a significant effect on financial performance (ROA). The researcher recommended that the selected companies must consider the listed decision on the Libyan stock market; even when their financial performance is good.
\end{abstract}

Keywords: Non-oil manufacturing industries, Financial performance, Stock market 


\section{Introduction}

\subsection{Background of the Study}

The non-oil manufacturing an industry is one of the most important contemporary economic industries, because of their role and high impact in the local economy development and in a global level. The non-oil manufacturing sector plays significant role which cannot be ignored in the process of economic development in any state, and this sector occupies an increasing importance in the development plans in developing countries.

It seeks to break the cycle of industrial underdevelopment in order to achieve economic development, miscellaneous contribution to increase national income. The non-oil manufacturing industries are still one of the most powerful engines for economic structure of countries. Libya is one of the developing countries which focus on the non-oil manufacturing industries sector, through an ambitious industrial development plans prepared for this sector. This is to encourage the players in the Libyan economy to contribute to the progress of the national economy, increase the rate of growth and diversify the production and reduce the dependence on oil to a level necessary for financing the transformation plan, reduce imports, increase the non-oil exports and expand the economic infrastructure.

For that Libya spent 4500 million Libyan dinars (LND) approximately 6 billion (U.S.D), for the development of the industries sector. This translated to $17 \%$ of the total expenses of the development plans during the period from 1970 to 1990 (Buzied, 1998). The oil sector still contributes approximately $95 \%$ of export earnings, $75 \%$ of the government receipts and from $30 \%$ to $40 \%$ of the gross domestic product (Khaled et al, 2010).

The Libyan economy still lacks of diversification as the Libyan economy depends heavily on crude oil as source of income. According to annual reports of OPEC in 2005, shows, that the value of Libyan export of crude oil from 1999 to 2005, was about $99 \%$ in 2005, while other exports was only $1 \%$ (Edwik, 2007). It is the interest of the researcher to examine the reason for the inability of the non-oil manufacturing sector to be a main resource and an active contributor to the Libyan economy.

The lack of economic diversification in Libya is still evident after the introduction of the stock market in 2007. Stock market is an important tool to support the development of the national economy and diversifying its sources in developed and developing countries, through the promotion of the exchange of goods and services and domestic and international resource mobilization. According to (Al-Jabiri, 2012) the strong stock markets play significant role in supporting national economic development, because they enhance the exchange of goods and services, and the mobilization of resources for both domestic and international market. The literature and economic studies indicate that there is a strong positive relationship between financial markets and national economic growth (Ross, 1997).

It is necessary to create a market for securities in Libya which aimed to contribute to economic growth in Libya, by enhancing savings mobilization, financial sector competition, facilitating the conduct of monetary policy through indirect instrument, and attracting much needed foreign capital. The non-oil manufacturing companies that are listed on Libyan stock 
market in 2008 are: Cement Company, Pipe Manufacturing Company, Tobacco Company, mills and Fodder Company, Cables Company, Pipeline Company, engineering Industries Company and extraction and refining of Vegetable Oils Company, but the contribution of these companies is still low as the oil sector still contributes approximately $95 \%$ of export earnings, $75 \%$ of the government receipts and from $30 \%$ to $40 \%$ of the gross domestic product (GDP). Accordingly, the researcher attempt to answer the following question " Is the current financial performance of non-oil manufacturing companies listed on the Libyan stock market (LSM), qualify them to be contribute effectively to the growth of the Libyan national economy, through this market?" The subject of financial performance has received significant attention from scholars in the various areas of business and strategic management. Financial performance is one of the important performance measures for economic units. Financial performance measurement is used as the indicator to evaluate the success of economic units in achieving stated strategies (Katja, 2009).

Financial performance has implications to manufacturing companies health and ultimately its survival, high financial performance reflect management effectiveness and efficiency in making use of firms resources and this in turn contributes to the country's economy at large (Kamal \& Mohd, 2004 ). The main objective of financial performance measurement is to determine the operating and financial characteristics and to determine the efficiency and performance of economic unit management as reflected in the financial records and reports (Amalendu, 2010).

\subsection{The Research Problem}

The main motivation for this study was to answer the main question is "Is the financial performance of non-oil manufacturing companies listed on the Libyan stock market (LSM), able to contribute effectively to the growth of the Libyan national economy, through this market?", for to answer this question the researcher will to examine the financial performance of non-oil manufacturing companies. This is to assist the decision makers in this sector to improve their performance, so that these companies could become an important source for the national economy, along with the oil sector. The manufacturing industrial sector contributes not more than 5 per cent to the gross domestic product (GDP).This is insignificant when compared to the oil sector's contribution that is more than 60 per cent in 2004. The low percentages of real gross domestic product (GDP) of manufacturing industrial sector may be the result of low-level of financial performance in this sector.

Hence, this study seeks to assess and estimate the level of financial performance and identifies the factors affecting in this performance of non-oil manufacturing companies listed on Libyan stock market (LSM). The best performance of any economic unit plays the main role in increasing the added value of that specific economic unit, coupled with the role of leading towards the growth of the whole industry sector, which ultimately leads to the overall success of the national economy.

Accordingly, this problem may lies in the weakness of financial performance in the following areas: liquidity, activity and profitability. This in turn reflects on financial performance in this 
sector and leads to inability to optimal exploit of the material and financial resources available.

\subsection{Objectives of the Study}

The main objective of this study is to assess the financial performance and to explore the respondents' views on the factors affecting the financial performance during the period of the proposed study. To achieve the main objective the study will cover the following specific objectives:

1-To measure the relationship between liquidity performance and financial performance in the non-oil manufacturing companies listed on the Libyan stock market during the period of study.

2-To measure the relationship between operational efficiency performance and financial performance in the non-oil manufacturing companies listed on the Libyan stock market during the period of study.

3-To measure the relationship between selling and general administrative expenses performance and financial performance in the non-oil manufacturing companies listed on the Libyan stock market during the period of study.

4-To measure the relationship between company size and financial performance in the non-oil manufacturing companies listed on the Libyan stock market during the period of study.

5-To measure the relationship between company age and financial performance in the non-oil manufacturing companies listed on the Libyan stock market during the period of study.

6-To explore the views and perceptions of decision makers in the non-oil manufacturing companies listed on the Libyan stock market which related to the issues of financial performance.

\subsection{Significance of the Study}

The main reason to choose this study is that the researchers have not paid enough attention to this subject in Libya, while the most of the previous studies focused on banks and insurance not on the non-oil industrial companies, as well as some focused on only evaluation of financial performance not on factors affecting financial performance. This study will examine the impact of financial factors on financial performance of the non-oil manufacturing companies listed on the Libyan stock market (LSM).

This study will contribute to the body of knowledge by identifying how the non-oil industrial companies develop their financial performance in order to improve the competitiveness and quality of the manufacturing sector, to enhance their efficiency, to multiply profitability and maximize wealth of shareholders, to contribute effectively in the Libyan national economy and to be used as resource information for future studies on factors affecting firm's financial performance. 


\section{Review of the Previous Studies}

Many researchers have studied the topic of financial performance from different views and different angles in different environments, are as follows:

Faisal, et al., (2012) examined the relationship between working capital and profitability. Linear regression model with ordinary least square (OLS) was used to analyze the data collected from 25 Pakistani manufacturing companies listed on Karachi stock exchange during the period from 2001 to 2010. The average of return on asset ratio (ROA) was used as proxy for profitability. The analysis showed that there was a significant negative relationship between current ratio and return on assets, while there was a significant positive relationship between quick ratio and return on assets.

Farzaneh and Amin (2012) studied the relationship between traditional and modern liquidity ratios and profitability. Multiple regression method was used to analyze the data collected from 108 companies of five different industries listed in Tehran stock exchange, during the period of 2002 - 2010. They found that there is a negative and significant relationship between current ratio and return on assets. They also found that there is a positive and significant relationship between quick ratio and return on assets.

Zubair and Muhammad (2013) examined the impact of working capital management on profitability. Multiple regression analysis was used to analyze the data collected from 21 Pakistan cement industry companies listed on Karachi stock exchange for the period of 2004-2010. Return on assets serves as a profitability measure. The study finds that there is a positive association between current ratio and return on assets; also, there is a negative association between quick ratio and return on assets.

The aim of Vijayakumar study (2011) was to explore the effect of cash conversion cycle on the profitability. The study used panel data regression and performed analysis on a sample of 20 firms in Indian Automobile industry for the period 1996 -2009. The results suggest that there is a negative and significant relationship between variables of inventory turnover ratio and accounts receivable turnover ratio and return on assets.

Shaskia (2012) measured the relationship between working capital management and profitability of 70 firms listed in the Euronext in the Netherlands for the period of 2006 2010. The methodologies employed in this study are Ordinary least square and fixed effect model which are used for the data analysis. The study found that the result of pooled ordinary least square regression shows a positive and significant relationship between inventory turnover ratio and return on assets whereas the fixed effects models shows that there is negative but insignificant relationship between these two variables. Moreover, the relationship between receivables accounts and the return on assets in the fixed effect model (positive relationship) contradicts the result in the pooled ordinary least square model which shows that there is a significant negative relationship between accounts receivable ratio and return on assets.

Okwo and Ugwunta (2012) examined the effect input costs on profitability of four industrial companies listed on Nigerian stock exchange for a period from 1999 to 2010. The average of 
gross profit margin (GPM) was used as proxy for profitability. The methodology employed in this study (Ordinary least square) was used for the data analysis. The study also found a positive and significant relationship between selling and general administrative expenses ratio and gross profit margin.

Taiwo (2012) investigated the impact of capital structure on firms' performance on of manufacturing companies on the Nigerian stock exchange, during the period 2000-2010. In this study, the dependent variable return on assets considered as a criterion to measure performance and the ordinary least squares analysis was used to analyze the study data. The results suggested that there is a positive and insignificant relationship between variables of company size and company age and return on assets.

Akinyomi and Olagunju (2013) examined the effect of firm size on profitability. Multiple regression method was used to analyze the data collected from 5 manufacturing companies listed on Nigerian stock exchange. The period of the study covered the years between 2005 and 2012. Return on assets serves as a profitability measure. They found that there is a significant positive relationship between company size (LN sales) and return on assets.

\section{Study Methodology}

\subsection{Population and Sample of the Study}

Population is a group of cases that meet particular requirements related to the problem studied (Septika, 2010). Sample is a part of the whole population that becomes the aim of research. There are four models of sampling which are random sampling, cluster sampling stratified sampling and purposive sampling (Septika, 2010). The study population consists of eight (8) non-oil manufacturing companies. The sample of this study covers the eight non-oil manufacturing companies listed on the Libyan stock market (LSM) during the period from 1999 to 2008. The sample was chosen by purposive sampling and the criteria for the selection of this sample are: the companies that have published its complete financial statements for ten year, the companies' financial year - end is December; the companies that do not have negative equity. Table 1 , shows the sample of study.

Table 1. Sample of the study

\begin{tabular}{lllll}
\hline No & Company Name & Symbol & Industry & Incorporation Date \\
\hline 1 & Ahlia Cement Company & ACC & Manufacturing & 1965 \\
\hline 2 & $\begin{array}{l}\text { Al- Enmaa Company For Pipe } \\
\text { manufacturing }\end{array}$ & AECPM & Manufacturing & 1968 \\
\hline 3 & Libyan Company Of Tobacco & LCT & Manufacturing & 1972 \\
\hline 4 & $\begin{array}{l}\text { The National Company } \\
\text { Mills \& Fodder }\end{array}$ & TNCMF & Manufacturing & 1973 \\
\hline
\end{tabular}




\section{$5 \quad$ Al- Enma Company For Cables $\quad$ AECC $\quad$ Manufacturing 1976}

\begin{tabular}{llllll}
\hline 6 & $\begin{array}{l}\text { Al-Enma } \\
\text { Pipeline }\end{array}$ & Company & For AECP & Manufacturing & 1978 \\
\hline 7 & $\begin{array}{l}\text { Al- Enmaa } \\
\text { Extraction and Refining of } \\
\text { Vegetable Oils }\end{array}$ & Company AECERV & Manufacturing & 1986 \\
\hline 8 & $\begin{array}{l}\text { Al- Enma Company } \\
\text { Engineering Industries }\end{array}$ & For & AECEI & Manufacturing & 1995 \\
\hline
\end{tabular}

Source: Researcher design

\subsection{Data Collection Methods}

According to Sekaran; (2003) data collection methods are an integral part of study design and it depends primarily on objectives and approach of the study. There are a set of methods that are used to collect data such as experiment, observation and survey, or from primary and secondary sources and the selection of the methods depends on the type of the research design that have been being conducted (Benjalux, 2006).

The primary data source is about creating new data by doing surveys and carrying out interviews, while the secondary data sources is about collecting and analyzing existing data (Khwaja and Muhammad, 2009). The secondary data refers to information gathered from sources that are already existed such as annual reports of firms, government publications of economic indicators, as well as traditional books, published articles and journals (Zikmund, 2000).

The present study mainly based on secondary and primary data. The secondary data for this study was collected from the financial statements published by the financial departments of non-oil manufacturing companies listed on Libyan stock market (LSM) during the period of the study namely the balance sheet and income statement, the final number of financial statements was 160 annual statement from 8 companies in the period ten years, while the primary data for this study was collected from interviews (semi-structured) with financial managers to increase the validity of data gathering via qualitative research.

Moreover, the researcher used other resources such as books texts, thesis and Journals in order to collect the scientific content of the theoretical framework of the study and to explain the basic concepts of the study. In this study the researcher used quantitative and qualitative research methods to analyze data. The first phase of data analysis is the quantitative research which includes method of the statistical analysis in order to determine the factors affecting the financial performance in the study sample, while the second phase is the qualitative research which includes method of the semi-structured interview. 


\subsection{Statistical Analysis}

This study has two main targets. The first one is to identify to what extent the independent variables affects the dependent variable, and also to identify the type of relationship and correlation between variables and testing the hypotheses. To achieve these aims, the study will use descriptive statistics, correlation test and regression analysis. This study undertakes the issue of identifying key variables that influence financial performance in a sample of the proposed study.

\subsubsection{Variables Selection of the Study}

The researcher choice of the variables that have been used in this study, are influenced by the previous studies related the subject of financial performance. All the variables stated below have been used to test the hypotheses of our study. They include dependent and independent variables.

\subsubsection{Dependent Variable (DV)}

According to Benjalux (2006) the dependent variable is the variable that is predicted by one or more independent variables. The dependent variable is the variable of primary interest to the research and is to be explained (Sekaran, 2003). In this study, the financial performance is a dependent variable measured by return on assets (ROA). Return on assets (ROA) is used in this study because it shows the profit earned per unit of assets, as well as reflects the management's ability to utilize the economic units financial and real investment resources to generate profits. It is considered to be most reliable measure of financial performance as the asset values always are non-negative (Gray et al, 2004). Return on assets (ROA) is calculated by net income over total assets.

\subsubsection{Independent Variables (IV)}

The independent variables are the cause that affects the dependent variables either positively or negatively (Sekaran, 2003). This study used eight independent variables include:-

\subsection{Current Ratio (CR)}

Current ratio (CR) is considered to be the most and commonly used ratio to measure the liquidity position in the economic units in general and in the manufacturing sector in particular (Vanitha \& Selvam, 2007). The major objective of this ratio is to measure the ability of the firm to meet its short term liability, from current assets, which can be converted into cash in the short term. It is mainly used to show the economic unit ability to pay back its short-term liabilities (debt and payables) with its short-term assets (cash, inventory, receivables) (Michael \& Romuaid, 2006).Current ratio is calculated by current assets over current liabilities.

\subsection{Quick Ratio (QR)}

Quick ratio is chose as the independent variable for the liquidity performance, as it measures the ability of the economic unit to meet its short-term of its assets quick shift to cash, because the quick ratio only takes into consideration the cash and assets that can be easily converted 
into cash such as prepaid expenses, some taxes, and employee, related prepayments. Quick ratio is the most rigorous and penetration test of the liquidity position of the economic unit as compared to the current ratio of the firm (Mandal \& Mahavidyalaya, 2010). Quick ratio is calculated by current assets-(inventory+ prepayments) over current liabilities.

\subsection{Net Working Capital (NWC)}

The main reason behind chosen this ratio as a variable for the liquidity performance is that because it is one of the important financial elements to evaluate financial performance in the economic units. It is also a useful indicator in the field of financial management as it reflects the efficiency of the economic unit in the use of available cash in order to meet current liabilities; (Pirvutoiu \& Agatha, 2007). Net working capital is calculated by current assets minus current liabilities.

\subsection{Inventory Turnover Ratio (ITR)}

The reason for choosing this ratio as a variable for the operational activity performance is that because it is the critical performance to assess the effectiveness of inventory management in the economic unit. It is one of the main parts for all business operations because there is a direct relationship between level of inventory and sales, as long as this ratio is higher, it is better because it refers to the ability of the economic unity on the sale of its inventory and reduces the chances of obsolete inventory, and uses available resources in an efficient and effective way; (Noor et al., 2009). Inventory turnover ratio is calculated by net sales over average inventory.

\subsection{Account Receivable Turnover Ratio (ARTR)}

The study chose this ratio as a variable for the operational activity performance, because it measures the speed of movement of inventory from the point of purchase of raw materials to the point of sale of commodities ready for sale. This ratio indicates that there is a relationship between incomes from sales to the amounts receivable within one year; it indicates how rapidly an economic unit receives payments for goods and services sold and reflect its capability of securing payments (Misiunas, 2010). The high value of this ratio indicates the effectiveness of the credit policy in the economic unit (Krishna et al., 1984). This ratio calculated by net sales over average account receivables.

\subsection{Selling and General Administrative Expenses Ratio (SGAER)}

The reason for choosing this ratio as a variable for this study is that, because it is designed to capture the impact of a firm selling and general administrative expenses on profitability. This ratio also provides a measure of the risk assumed from the manufacturer's contractual obligations; (Arthur, 2012). Hence, it is important for us to know how managers manage these expenses because the ratio of selling and general administrative expenses is closely monitored by investors and analysts; (Anderson et al., 2006). This ratio calculated by selling and general administrative expenses over net sales X 100. 


\section{MlMacrothink}

International Journal of Accounting and Financial Reporting

ISSN 2162-3082

\subsection{Company Size (CZ)}

Researcher chose this variable for this study because the company size plays an important role in determining the capital structure of a company and it affects liquidity, profitability and thus, affects the financial performance in different ways. This variable can exploit economies of scale, physical capita scope and employs more skilled managers and formulate the procedures that may lead to better performance, thus this variable is more efficient especially in the large companies compared to small firms; (Amal et al; 2012). The increasing economies of scale will decrease the average cost of production, thereby, the return on capital will increase and affect company size increasing; (Prasetyantoko \& Parmono, 2008). Company size has been considered as an important determinant of company profitability as it measures a company's market power or the level of concentration in the industries in which the company operates; (Babalola, 2013). This variable calculated by natural log (Total sales).

\subsection{Company Age (CG)}

The main reason for choosing this variable in this study is that because the company age is an important variable to determine the financial performance of any company (Chandrapala, 2013). When the company becomes older, it enjoys economics of scale and enjoys the superior performance, this means that the companies can produce products at lower costs and this will cause an increase in sales and profits (Chandrapala \& Guneratne, 2012). Older companies have the early mover advantage and may possess specific competencies and skills; they are able to grow faster to achieve higher profitability (Bala et al., 2005). At the same time, if the older companies don't change their systems to cope with the new environmental conditions, their current financial performance would be worse (Chandrapala, 2013). This variable calculated by number of years since incorporation until the date for which data are incorporated.

\subsubsection{Study Model}

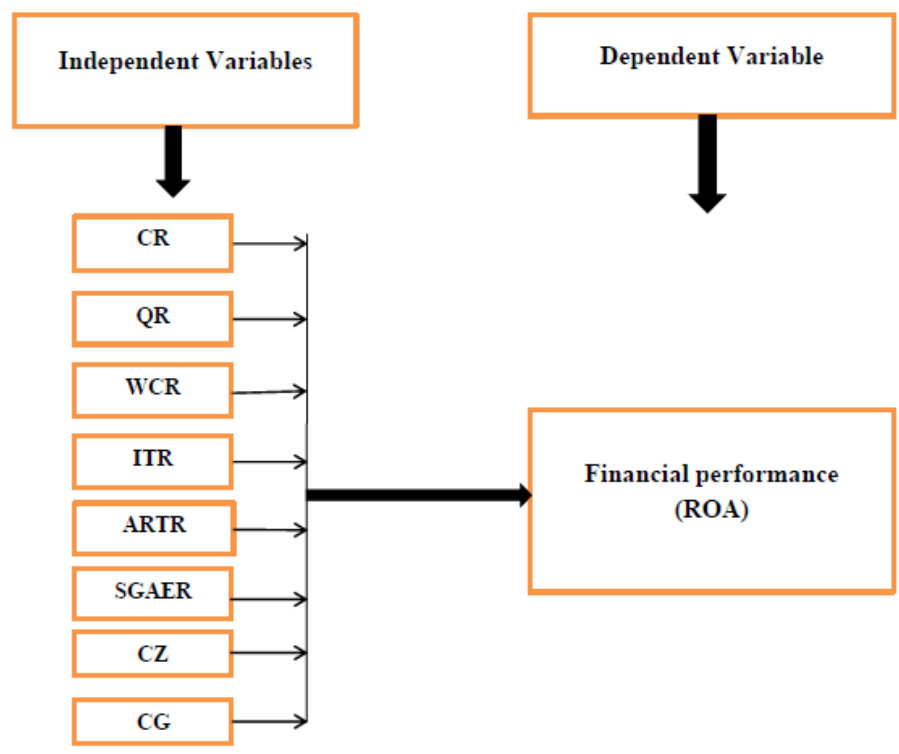

Figure 1. Study model 


\subsubsection{Study Hypotheses}

The null hypotheses of this study are as follows:

1- There is statistically significant relationship between current ratio (CR) and financial performance (ROA).

2- There is statistically significant relationship between quick ratio (QR) and financial performance (ROA).

3- There is statistically significant relationship between net working capital (NWC) and financial performance (ROA).

4-There is statistically significant relationship between inventory turnover ratio (ITR) and financial performance (ROA).

5-There is statistically significant relationship between account receivables turnover ratio (ARTR) and financial performance (ROA).

6- There is a significant relationship between selling and general administrative expenses (SGAER) and financial performance (ROA).

7-There is statistically significant relationship between company size (CZ) and financial performance (ROA).

8- There is statistically significant relationship between company age (CG) and financial performance (ROA).

\subsection{Semi-Structured Interviews Method}

The researcher involved a descriptive analysis of the data collected from the interviews method to examine the financial performance by using the opinions of financial managers of non-oil manufacturing companies listed on Libyan stock market. The interview is one of the most widely method used in qualitative research, and it is also one of the most significant sources of case study (Bryman \& Bell, 2004).It is an essential foundation of case study and it will be a led discussion rather than structured questions (Yin, 2003). The interviews method divided into three types which are: structured, semi-structured and unstructured interviews that can be used as data collection methods of a research.

The structured interview aims to catch precise data of a cod able nature for a deeper understanding of behavior within pre-established categories (Denzin \& Lincoln, 2000). The kind of interview used in this study is semi-structured interviews which were conducted with those who are responsible in the non-oil manufacturing companies listed on Libyan stock market, because the semi-structured interview used to obtain the information that it cannot be anticipated in advance, from interviewees that and the interviewer, as well as the Semi-structured interviews is important to state that they were used to obtain a clearer understanding of the whole problem to allow the researcher to focus on particular themes that emerged in the statistical analysis findings and to explore them. 


\subsection{Interview Sample}

Financial managers were interviewed because, to some extent, they have formulated opinions on financial performance. The total number of interviewees was 8 from 8 non-oil manufacturing companies listed on Libyan stock market. The perceptions of financial managers were reflected about the relationship between the effect of selected factors and financial performance. Therefore, the theoretical design of the sample was to get a support testing the effectiveness of the hypotheses that have been addressed in this study.

\section{Data Analysis and Results}

In this study, we have used two types of data analysis; descriptive statistics analysis and quantitative analysis (correlation analysis and regression analysis) using SPSS software version 17.0 to analyze quantitative data, which is collected from non-oil manufacturing companies listed on the Libyan stock market (LSM). After the raw data collection stage, this data is manually entered into an excel spreadsheet, and then uploaded into SPSS software for statistical analysis (See Table 1, in Appendix). Table 1 shows the raw data collected from the study that is covering the period from 1999 to 2008 and then it is important to screen the data, to check for missing data and outliers, before doing the actual process of statistical analysis of the variables, in order to examine and approve the quality of data.

When evaluating the data of this study, it is found that there is a problem of outliers in the most of the variables data of this study. This problem was treated through two methods, natural Log and square root. Under the natural $\log$ transformation, it is found that two variables were normal, namely the inventory turnover ratio (ITR) and selling and general administrative expense ratio (SGAER), while under the square root transformation, there are four variables, which are the current ratio $(\mathrm{CR})$, quick ratio $(\mathrm{QR})$, net working capital (NWC), account receivable turnover ratio (ARTR).

\subsection{Descriptive Statistics}

Descriptive statistics is the foundation stone for any type of analysis which enables the researcher to describe the relevant aspects to all the study variables that will entail detailed information about each relevant variable (Saswata, 2012). Descriptive statistics is derived from statistical analysis before another test performed using multiple regression analysis (Djoko, et al., 2009). It can be seen from Table 2, that the return on assets (ROA) has a mean value of 7.82 per cent of the total assets of all companies in the study sample and its standard deviation is 0.542 per cent. This figure means that the value of return on assets (ROA) can deviate from mean to both sides by 0.542 per cent, which implies the presence of moderate variations among the values of return on assets across the study sample. The values of standard deviation (SD) for all the variables in this study are generally small; this means that the data of this study are distributed near the mean and means also, that the analysis of multiple regression of the current study will be lead to significant results indicating the strength of the data. The values of coefficient of variation (CV) for all the variables in this study are low. It ranges from 0.021 to 0.639 , this means that the variables of this study have less variability and higher in the consistency and stability. The values of skewness for all 
variables in this study are ranging from -0.672 to 0.607 , while the values of kurtosis for all the variables are ranging from -1.000 to 0.471 , based on these results we can say that the skewness and kurtosis scores of the current data in this study indicate an approximately normal distribution.

Table 2. Descriptive statistics for all variables

\begin{tabular}{lllllllll}
\hline Variables & $\mathrm{N}$ & Min & Max & Mean & SD & C V & Skewness & Kurtosis \\
\hline ROA & 80 & 7 & 9 & 7.82 & 0.542 & 0.069 & -0.025 & -0.291 \\
\hline CR & 80 & 1 & 2.9 & 1.67 & 0.393 & 0.235 & 0.607 & 0.471 \\
\hline QR & 80 & 0.71 & 2 & 1.24 & 0.278 & 0.224 & 0.374 & -.0 .151 \\
\hline NWC & 80 & 2.57 & 2.92 & 2.72 & 0.085 & 0.031 & -0.014 & -0.494 \\
\hline ITR & 80 & -1.00 & 0.91 & -0.024 & 0.473 & 0.021 & -0.153 & -0.537 \\
\hline ARTR & 80 & 0.32 & 3.16 & 1.650 & 0.815 & 0.493 & 0.236 & -1.000 \\
\hline SGAER & 80 & -0.52 & 2.30 & 1.018 & 0.651 & 0.639 & -0.107 & -0.312 \\
\hline CZ & 80 & 6 & 9 & 7.24 & 0.741 & 0.102 & -0.184 & -0.576 \\
\hline CG & 80 & 4 & 43 & 26.88 & 9.664 & 0.359 & -0.672 & -0.294 \\
\hline
\end{tabular}

Source: SPSS 17.0

\subsection{Correlation Test}

According to Wajahat and Syed (2010) before starting the regression analysis it is important to check the correlation test between dependent variable and independent variables. The correlation test scale ranges from -1 to +1 and any value greater than zero indicates a positive direct relationship between the two variables, which implies that every increase in the independent variable will led to the increase in dependent variable, while any value less than zero indicates a negative indirect relationship between the two variables. According to, Table 3 , the correlation coefficients between all the variables in this study at 0.05 and 0.01 level of significance for all the variables employed in the study, present that the ROA is significantly related with selling and general administrative expenses (SGAER) under 0.01 confidence level, while the ROA is significantly related with current ratio (CR) net working capital (NWC) company size (CZ) and company age (CG), under 0.05 confidence level.

However, ROA is insignificantly correlated with quick ratio $(\mathrm{QR})$, inventory turnover ratio (ITR), and account receivable ratio (.the correlation coefficients between independent 
variables are range from -0.538 to 0.609 as shown in Table 4 . So, from the results, it can be concluded that the Pearson correlation analysis indicates that the correlations between the independent variables in this study are low and this means that there is no multicollinearity problem exists in the model, because there is no value greater than 0.8 .

Table 3. Correlation test between ROA and independent variables

\begin{tabular}{lll}
\hline Independent Variables & Pearson correlation & Significant \\
\hline CR & $-0.295^{* *}$ & $(0.008)$ \\
\hline QR & 0.082 & $(0.468)$ \\
\hline NWC & $0.848^{* *}$ & $(0.000)$ \\
\hline ITR & 0.121 & $(0.287)$ \\
\hline ARTR & -0.037 & $(0.746)$ \\
\hline SGAER & $0.228^{*}$ & $(0.042)$ \\
\hline CZ & $0.628^{* *}$ & $(0.000)$ \\
\hline CG & $0.349^{* *}$ & $(0.002)$ \\
\hline
\end{tabular}

* Correlation is significant at the 0.05 level (2-tailed). ** Correlation is significant at the 0.01 level (2-tailed).

Source: SPSS 17.0

Table 4. Correlation test between independent variables

\begin{tabular}{|c|c|c|c|c|c|c|c|c|}
\hline Variables & $\mathrm{CR}$ & QR & ITR & NWC & ARTR & SGAER & $\mathrm{CZ}$ & $\mathrm{CG}$ \\
\hline $\mathrm{CR}$ & 1 & & & & & & & \\
\hline \multirow[t]{2}{*}{ QR } & $0.609^{* *}$ & 1 & & & & & & \\
\hline & $(0.000)$ & & & & & & & \\
\hline \multirow[t]{2}{*}{ NWC } & 0.035 & $0.384^{* * *}$ & 1 & & & & & \\
\hline & $(0.757)$ & $(0.000)$ & & & & & & \\
\hline \multirow[t]{2}{*}{ ITR } & 0.146 & $0.326^{* *}$ & 0.144 & 1 & & & & \\
\hline & $(0.197)$ & $(0.003)$ & 0.203 & & & & & \\
\hline \multirow[t]{2}{*}{ ARTR } & -0.042 & -0.038 & 0.016 & $0.516^{* *}$ & 1 & & & \\
\hline & $(0.714)$ & $(0.740)$ & $(0.887)$ & $(0.000)$ & & & & \\
\hline
\end{tabular}




\begin{tabular}{lllllllll}
\hline SGAER & -0.102 & -0.116 & 0.154 & $-0.538^{* *}$ & $-0.521^{* *}$ & 1 & & \\
& $(0.367)$ & $(0.306)$ & $(0.174)$ & $(0.000)$ & $(0.000)$ & & & \\
\hline CZ & -0.143 & 0.149 & $0.617^{* *}$ & $0.460^{* *}$ & $0.442^{* *}$ & -0.272 & 1 & \\
& $(0.204)$ & $(0.186)$ & $(0.000)$ & $(0.000)$ & $(0.000)$ & $(0.015)$ & & \\
\hline CG & -0.084 & -0.038 & $0.341^{* *}$ & 0.076 & $0.303^{* *}$ & $-0.378^{* *}$ & $0.446^{* *}$ & 1 \\
& $(0.457)$ & $(0.738)$ & $(0.002)$ & $(0.502)$ & $(0.006)$ & $(0.001)$ & $(0.000)$ & \\
\hline
\end{tabular}

* Correlation is significant at the 0.05 level (2-tailed). ** Correlation is significant at the 0.01 level (2-tailed).

Source: SPSS 17.0

\subsection{Multicollinearity Test}

According to Gujarati (2003) one of the assumptions of linear regression model is that there is no multicollinearity among the independent variables. Multicollinearity test aims to test the regression model to know if there is a correlation between independent variables or not (Rafika \& Muhamad, 2012). Table 5, shows that the multicollinearity does not exist among all independent variables, because the tolerance values for all independent variables in this study is more than 0.10 , it's ranging from 0.343 to 0.557 , while the values of variance inflation factor (VIF) for all the independent variables are less than the limited valued 10.0 it's ranging from 1.796 to 2.935 . It can be concluded that there is no multicollinearity, because the variance inflation factor (VIF) and tolerance values were within acceptable required range.

Table 5. Results of multicollinearity test

\begin{tabular}{lll}
\hline Variables & Tolerance & Variance Inflation Factor (VIF) \\
\hline CR & 0.557 & 1.796 \\
\hline QR & 0.419 & 2.388 \\
\hline NWC & 0.341 & 2.935 \\
\hline ITR & 0.446 & 2.442 \\
\hline ARTR & 0.546 & 1.830 \\
\hline SGAER & 0.421 & 2.378 \\
\hline CZ & 0.343 & 2.919 \\
\hline CG & 0.549 & 1.820 \\
\hline
\end{tabular}

Source: SPSS 17.0 


\section{MlMacrothink}

International Journal of Accounting and Financial Reporting

ISSN 2162-3082

2019, Vol. 9, No. 4

\subsection{Autocorrelation Test}

Autocorrelation test can be controlled by Durbin-Watson (DW). Durbin-Watson d value can be a range from 0 to 4 (Bayouda, et al., 2012). It can be seen from the results of Table 6, which the value of Durbin-Watson statistic, that was used to test the auto correlation for the model of study, can range from 0 to 3 . The Durbin-Watson values in these data are 2.42 and are not greater than 3 or less than 1 .

This result, which means that there is no auto-correlation or serial correlation, presents a problem with the data, this also means that the model of study is valid and the errors are not correlated.

Table 6. Results of autocorrelation test

\begin{tabular}{llll}
\hline Model & $\mathrm{R}$ & Standard Error of the Estimate & Durbin-Watson (DW) \\
\hline 1 & .935 & .204 & 2.42
\end{tabular}

Source: SPSS 17.0

\subsection{Heteroscedasticity Test}

Heteroscedasticity test aims to test whether the regression has difference variance from the residue between observations; (Djoko, et al., 2009). The result of heteroscedasticity test can be shown from the Figure 2. There is no heteroscedasticity, because the points on the below graph formed a scatter plot not a clear pattern. As well as, the spread is above and below the 0 on the $\mathrm{Y}$ axis. So that it can be concluded that there is no heteroscedasticity in the regression model, and this result, means that the standard deviations of the residuals are reliable.

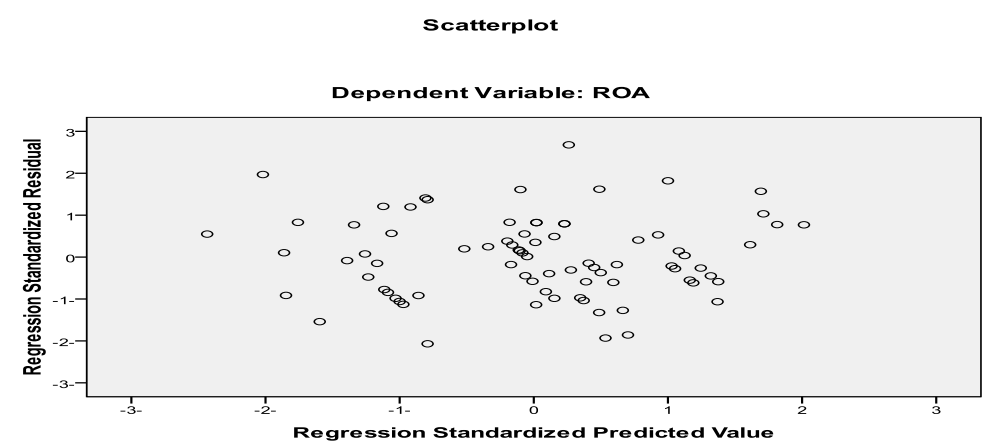

Figure 2. Scatter plot: regression standardized predicted value

\subsection{Multiple Regression Analysis}

After evaluating the study data, through several important tests, namely as multicollinearity test, autocorrelation test and heteroscedasticity test, we can say that the data was ready and could be used to run a multiple regression analysis. As it can be seen from the results of Table 7, that the multiple regression analysis results show that the sing of current ratio (CR), 
quick ratio $(\mathrm{QR})$, net working capital (NWC), inventory turnover ratio (ITR), account receivable turnover ratio (ARTR), selling and general administrative expense ratio (SGAER), and company size (CZ) and company age (CG) is from 0.000 to 0.078 . It indicates that the eight variables have a significant linear relationship with the return on assets (ROA).

$\mathrm{C}$ is the constant where the regression line intercepts the $\mathrm{y}$ axis, representing the dependent value $\mathrm{y}$ and this case happen when all the independent variables are zero. In this study the value of $\mathrm{C}$ is -4.559 ; the probability of the coefficient is significant with $\mathrm{p}$ - value of 0.000 . The multiple linear regression model identified for the variables studied is estimated as the following equation:-

$$
\begin{aligned}
\mathrm{ROA} & =-4.559-0.322 \mathrm{CR}-0.227 \mathrm{QR}+4.493 \mathrm{NWC}+0.230 \mathrm{ITR}-0.116 \mathrm{ARTR} \\
& +0.157 \text { SGAER+0.115 Ln CZ+0.007 CG +e }
\end{aligned}
$$

Table 7. Multiple regression analysis

\begin{tabular}{lllll}
\hline Variables & Coefficient & Std. Error & t-Statistic & Sig. \\
\hline CR & -0.322 & 0.078 & -4.124 & 0.000 \\
\hline QR & -0.227 & 0.127 & -1.786 & 0.078 \\
\hline NWC & 4.493 & 0.460 & 9.775 & 0.000 \\
\hline ITR & 0.230 & 0.072 & 3.179 & 0.002 \\
\hline ARTR & -0.116 & 0.038 & -3.048 & 0.003 \\
\hline SGAER & 0.157 & 0.054 & 2.896 & 0.005 \\
\hline CZ & 0.115 & 0.053 & 2.167 & 0.034 \\
\hline CG & 0.007 & 0.003 & 2.154 & 0.035 \\
\hline C & -4.559 & 0.975 & -4.678 & 0.000 \\
\hline
\end{tabular}

Dependent variable: ROA

Source: SPSS 17.0

\subsection{Semi-Structured Interviews}

The researcher has been made the face-to-face semi-structured interviews for explore the respondents' view on the factors affecting the profitability (financial performance) of the companies selected for the study. Six financial managers from non-oil manufacturing companies listed on the Libyan stock market were interviewed. Interviews lasted from half hour to one hour and a half. Interviews were conducted in the managers' offices, and notes were taken during the interviews. The interviews with the financial managers of companies are shown in Table 8. 
Table 8 . The financial managers of interviewed

No Financial managers of companies Symbol of company

1 Financial manager of Ahlia Cement Company

ACC

2 Financial manager of Al- Enma Company For Pipe manufacturing AECPM

3 Financial manager of Libyan Company Of Tobacco LCT

$4 \quad$ Financial manager of The National Company For Mills \& Fodder

TNCMF

5 Financial manager of Al- Enma Company For Engineering AECEI Industries

6 Financial manager of Al- Enma Company Extraction and Refining AECERVO of Vegetable Oils

Source: Researcher design

\subsection{Factors Affecting on Financial Performance}

1- The effect of the financial liquidity (current ratio, quick ratio and net working capital) on financial performance.

All the interviews confirmed that there is a direct effect between liquidity and profitability (financial performance) of any company, because the financial liquidity is a fundamental stone to the continuity of company's life and also the financial liquidity utilizes to finance the investments when the external finance is not available, and it is necessary to study the degree of financial liquidity of the company to ascertain its ability to meet their financial obligations in the short and long term and to maintain the balance between the liquidity and profitability in the company.

The following quotations by two of the financial managers, (TNCMF and AECEI) support what have been mentioned before. They said:

Yes, we confirmed that there are significant effects between financial liquidity and profitability, because, the financial liquidity and profitability are two important areas in financial management, and also are the two main purposes of working capital management of any company. A good financial management must take care of liquidity and profitability, because each one of them has its own importance. When the management doesn't care about liquidity, then, the company may face the problem of bankruptcy, also when the management doesn't care about profitability, then, the company cannot stay in the economic life for a longer time.

For the actual performance level of this factor in the companies, all financial managers of selected companies believe that the liquidity position in these companies is more satisfactory, for the reason that, the current assets in these companies are able to meet their financial obligations in the short-term when they become due. 
2- The effect of the inventory turnover ratio on financial performance

A number of financial managers show the effect of the significant inventory turnover factors on the financial performance of the economic unit. Three of the financial managers in the interviews (ACC, AECEI and TNCMF) stated that:

Yes, we think that there are significant relationship between inventory turnover factor and profitability (financial performance). We also think that this factor has a significant effect on the profitability, because, the inventory is one of the major items of the current assets. For that reason, the cash value of current assets, which are included directly or indirectly into produced goods in a production system, is kept for the future or with the intention of selling. It is also one of the most essential parts of the business operation of the company. The inventory is also an important tool in determining the profitability of the company, because the percentage of inventory constitutes from about 20 per cent to 60 per cent of company's current assets. On the other hand, a lower inventory turnover will indicate that an excessive company investment in inventory might be too low, weaker demand for the products offered by the company, poor quality of goods that leads to lower profit as compared to total investment and inefficient management of inventory etc.

For the actual performance level of the inventory turnover in all the selected companies in the study, all the responses were identical to the answer. As shown in the following quotation by four of the financial managers (AECPM, AECERVO, TNCMF and LCT) who stated that:

Yes, we confirmed that the level of inventory turnover is low; this decline is due to many reasons including the lack of administrative stability for these companies, as well as the lack of the inventory policies that have the ability to make the inventory at optimum level.

3- The effect of the account receivable turnover ratio on financial performance

All the interviews confirmed the account receivable turnover is a major factor that influence the level of financial performance, this belief, was expressed in the following comments:

Yes, I confirm that the account receivables factor is a very important component of a company's working capital, because it directly affects the liquidity and profitability level of any manufacturing company and it occupied the second most important place after inventory factor because, the percentage of the account receivables constitutes approximately 26 per cent of the company current assets (ACC).

Yes, in addition to this factor," we believe that the account receivable can be a complex field for the financial management in the company, maybe their decisions can both affect the company's value and the relationship with customers.

It is useful for financial management to think of the decision to grant credit in terms of carrying costs and opportunity costs associated with them, because, a company cannot invest their money elsewhere until and unless it collects its receivables. On the other hand, the financial management should make a stringent credit policy that protects the asset value and increases the liquidity of the company, because the type of customer and credit policy affect the level of investment in account receivables (LCT, TNCMF and AECEI). 
One of the financial managers (AECERVO), said:

The control of account receivables takes on additional importance and efficient collection determines both profitability and liquidity of the company, and it is important to maintain a reasonable quantitative relationship between receivables and sales.

For the actual performance level of this factor in all the selected companies, all the responses were identical to the answer. As shown in the following quotation by five of the financial managers, (ACC, AECPM, LCT, TNCMF and AECERVO) who stated that:

We confirm that the actual performance of the account receivable turnover factor in the companies that we work did not reach the level required (unsatisfactory) due to some reasons.

For example, because these companies that are adopted on the relaxed credit policy to collect their receivables from customers, this policy has reflected negative on the profitability. The level of accounts receivables is largely influenced by the credit policy offered by the economic unit to creditors. Also, the management of these companies did not adhere of the characters of the accounts receivables such as an element of risk, economic value and futurity.

4- The effect of the selling and general administrative expenses factor on financial performance

Almost all of the financial managers believe that there is a direct association between the selling and general administrative expenses and financial performance. The interviewees indicated that the raise of this factor may negatively affect the economic unit's profitability and it can also reflect the poor financial performance in the economic unit. For example, one of the financial managers in the interviews (ACC) said:

Yes, I think the selling and general administrative expense factor is also an important tool in determining the profitability of the company, because the percentage of this factor constitutes about 25 per cent to 27 per cent of the company's total assets. I think that there is also a significant relationship between this factor and profitability, because an increase in the ratio of this factor means that the company management is unable to adjust variable expenses, which affect the profit margin, as well as the difficulty of competing with other companies and vice versa.

All financial managers who were interviewed believe that the position of this factor in these companies is more satisfactory, because the percentage of selling and general administrative expenses is less than standard percentage.

5- The effect of the company size (total of sales) factor on financial performance

The interviewees believe that the company size in large companies is related to the economies of scale theory and physical capital scope. Then, these companies are able to benefit from the economies of scale, because the average unit of cost declines over the range of output plus. One of the financial managers' (TNCMF) said: 


\section{Mll Macrothink}

International Journal of Accounting and Financial Reporting

ISSN 2162-3082

2019, Vol. 9, No. 4

Yes, I believe that the company size factor has a major effect on the financial performance, particularly regarding large industrial companies, because the industrial companies have a larger number of branches, employees, clients, and shareholders. This is the case in my company.

Another financial manager, (AECPM), shared the same view and he said:

At the same time I believe that the size of a company can be measured by the total of sales, total number of employees and total of assets that the company owned in a certain year, as well as this variable can exploit the economies of scale and physical capital scope that may lead to better performance, which is more efficient than smaller firms. On the other hand, I believe that there is a relationship between company size and company sales, this means when the size of company increases, the sales and profit of the company increases, and it also means when the company becomes bigger, its ability to generate returns gradually improves.

6- The effect of the company age factor on financial performance

The respondents in the interviews held mixed views regarding the influence of the company's age on the financial performance. Some of the interviewees believe that the company's age is one of the most important factors used to determine the financial performance of any economic unit, because the older economic units have the early mover advantage and may possess specific competencies and skills; they are able to grow faster to achieve higher profitability, also when the economic units become older, they can enjoy the superior performance. In the other hand, other interviewees believe that the company's age may be a significant factor in determining the financial performance level in the economic unit, if the older companies change their systems to cope with the new environmental conditions. However, one of the interviewees, (ACC) expressed that older companies are more likely to provide good financial performance to stakeholders; the following excerpt is illustrative to this view:

Yes, I believe that the level of financial performance is influenced by the factor of company age, particularly regarding large industrial companies, because it seems to me that older companies have got more experience and more skills which allow them to prepare and provide more detailed financial information through their published annual reports. But at the same time, if the older companies don't change their systems to cope with the new environmental conditions, the financial performance would be worse. For this company, I believe that the management of this company is seeking to benefit from the long life of this company to improve all the areas like financial, administrative and productive, even this company can continue in the economic life and contribute effectively to the GDP.

\section{Conclusion of the Study}

In this study, the researcher used mixed methods of both quantitative (statistical analysis) and qualitative (semi-structured interviews) researches that have been adopted in order to get a better understanding of the financial performance level and to identify the affecting factors in this Performance of non-oil manufacturing companies listed on Libyan stock market (LSM), and this study used secondary and primary data for the period from 1999 to 2008 . The results 
regarding to the statistical analysis method (net working capital, inventory turnover ratio, selling and general administrative expenses ratio, and company size and company age), have a positive statistical effect on the financial performance(ROA), while the variables of (current ratio, quick ratio and account receivable turnover ratio), have a negative statistical effect on the financial performance (ROA).The results regarding to semi-structured interviews method, reveal that the respondents in the interviews were confirmed that the selected factors have a significant effect on financial performance (ROA). From the above conclusion the researcher concluded that the financial performance of the non-oil manufacturing companies listed on Libyan stock market during the study period from 1999 to 2008, were not satisfactory.

\section{Recommendations of the Study}

Based on the study results the following recommendations were presented for this study:

1- There is a significant increase in liquidity of the selected companies during the study period, because there are significantly and negatively associated between liquidity with financial performance. These results are inefficient because these funds should be used to increase the return through other investments are profitable. It is better for these companies to maintain a lesser amount of ready cash and to invest the money in convertible securities, and also the selected companies can increase profitability by reducing their liquidity position at least to the standard level, and also must set a trade-off between profitability and liquidity, so that neither the liquidity nor profitability will suffer.

2- There is weakness in the performance level of the operational activity (inventory turnover and account receivable turnover), this decline has led to the inability of these companies to convert their inventories into sales and inability to collect debts from its customers, this decline is effect on the profitability. So the selected companies should focus on working capital management, in order to increase their profitability by speeding the inventory turnover rate, by implicating inventory control system, and by improving their sales management.

3- The selected companies should consider the size of the company as the large companies have more resources, more accounting staff and sophisticated information systems that lead to high financial performance and can produce products at lower costs and generate the revenue and increase the profits. It is an important factor as it influences its competitive power.

4- The selected companies must consider the age of the company, because when the company becomes older, it may have built up reputation over the years and have acquired considerable experiences and this enable it to compete favorably in the market. It can also achieve experience - based economies that can be more proficient in gathering, processing, and releasing information when needed, and can avoid the liabilities of newness.

5- The selected companies must consider the listed decision on the Libyan stock market; even when their financial performance is good. 


\section{Implications of the Study}

In accordance to the objectives of this study, it can be drawn several of implications from the analysis and discussion of this study, these implications are as they follow:

1- This research is one of the first empirical studies that attempt to explain the financial performance of non-oil manufacturing sector in one of the developing countries. Furthermore, this research explains which operation practices positively affect the firm's performance. Consequently, it leads to higher financial performance in the selected companies of the study.

2- This study has definitely brought some valuable insights to the existing literature concerning financial performance as far as its pragmatic evidence is concerned, which identifies numerous factors such as; financial liquidity, inventory turnover, account receivable turnover, selling and general administrative expenses, company size and company age that have a major influence over the financial performance of the firm in the non-oil industry sector.

3- This study will help financial managers of non-oil manufacturing companies listed on Libyan stock market, to improve their financial performance and formulate policies that will promote effective financial system.

4- The contribution of this study is to analyze and measure the effect of a new variable on return on assets (ROA). This variable is selling and general administrative expenses ratio (SGAER) in accordance with references got by researcher.

\section{References}

Abdullah, K. A., \& Shabbir, M. (2009). A.P. Moller Maersk Group - A Company Analysis. MA thesis, Graduate Business School, Gothenburg University, Sweden.

Abiodun, B. Y. (2013). The Effect of Firm Size on Firms Profitability in Nigeria. Journal of Economics and Sustainable Development, 4(5).

Ali, W., \& Hassan, S. H. U. (2010). Relationship Between the Profitability and Working Capital Policy of Swedish Companies. MA thesis, School of Business, Umea University, Swedish.

Al-Jabiri, A. (2012). The Performance of Libyan Stock Market. ACTA Universitatis Agriculture ET Silviculture Mend liana Brunensis, LX3(7).

Amal, Y. A., Alamro, S. A., \& Al-Soub, Y. Z. (2012). Factors Affecting the Financial Performance of Jordanian Insurance Companies Listed at Amman Stock Exchange. Journal of Management Research, 4(2).

Anderson, M., Banker, R., Huang, R., \& Janakiraman, S. (2006). Cost Behavior and Fundamental Analysis of $S G \&$ A Costs.

Arshad, Z., \& Yasirgondal, M. (2013). Impact of Working Capital Management on Profitability a Case of the Pakistan Cement Industry. Interdisciplinary Journal of Contemporary Research in Business, 5(2). 


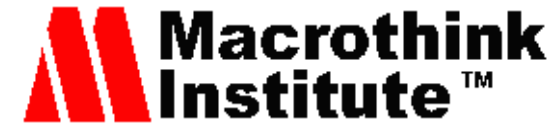

International Journal of Accounting and Financial Reporting

ISSN 2162-3082

Bayouda, N. S., Kavanagh, M., \& Slaughter, G. (2012, April). Factors Influencing Levels of Corporate Social Responsibility Disclosure by Libyan Firms: A Mixed Study. International Journal of Economics and Finance, 4(4).

Bhunia, A. (2010). Financial Performance of Indian Pharmaceutical Industry a Case Study. Asian Journal of Management Research.

Bryman, A., \& Bell, E. (2004). Business Research Methods. Oxford University Press, Oxford.

Buzied, M. M. ((1998). Enterprise Accounting and its Context of Operation: The Case of Libya. Ph. D Thesis, Durham University, United Kingdom.

Chatterjee, S. (2012). The Impact of Working Capital on the Profitability: Evidence from the Indian Firms. London School of Business \& Financial.

Denzin, N. K., \&. Lincoln, Y. S. (2000). The Discipline and Practice of Qualitative Research. Handbook of Qualitative Research, 2(3), 1-28.

Edwik, A. A. (2007). Oil Dependency, Economic Diversification and Development A Case Study of Libya. PhD thesis in Built and Human Environment, School of the Built Environment, The University of Salford.

Gujarati, D. N. (2003). Basic Econometrics (4th ed.). Mc Graw- Hill Companies.

Havser, M., \& Bert, R. (2006). Modeling the Relationship between Financial Indicators and Company Performances-An Empirical Study for US-listed Companies. Retrieved from http://epub.wu-wien.ac.at

John, A. O., \& Adebayo, O. (2013). Effect of Firm Size on Profitability: Evidence from Nigerian Manufacturing Sector. Prime Journal of Business Administration and Management, 3(9), 1171-1175.

Khaled, R. M., Elbeydi, A., Hamuda, M., \& Gazda, V. (2010). The Relationship between Export and Economic Growth in Libya Arab Jamahiriya. Theoretical and Applied Economics, XVII(1), 69-76.

Lahtinen, K. (2009). Assessing the Resource Usage Decisions and Financial Performance in Finnish Sawmills Within The Resource-Based View Framework. Faculty of Forest Sciences, University of Joensuu, Finland.

Leahy, A. S. (2012). The Determinants of Profitability in the Pharmaceutical Industry. American Journal of Health Sciences, 3(1).

Levine, R. (1997). Financial Development and Economic Growth: Views and Agenda. Journal of Economic Literature, XXXV, 688-726.

Lode, N. A. J. N. A., Ahmad, J. H., Abidin, A. Z., Ali, A., \& Aziz, N. M. A. (2009). Fundamentals of Accounting and Finance. Open University Malaysia (OUM). 


\section{MIMacrothink}

International Journal of Accounting and Financial Reporting

ISSN 2162-3082

2019, Vol. 9, No. 4

Mary, O. I., \& Okelue, U. D. (2012). Impact of Firm's Input Costs on Firm Profitability: Evaluation of the Nigerian Brewery Industry. Research Journal of Finance and Accounting, 3.

Misiunas, A. L. ((2010). Financial Ratios of the Country's Enterprises in the Face of Economic Growth and Decline. Economical, 89(1).

Naser, K., \& Mokhtar, M. Z. (2004). Determinants of Corporate Performance of Malaysian Companies. Fourth Asia Pacific Interdisciplinary Research in Accounting Conference, Singapore.

Nassirzadeh, F., \& Rostami, A. (2012). Studying the Relationship between Liquidity Indices (traditional and modern) and the Profitability of Companies Listed in Tehran Stock Exchange. Department of Accounting, Faculty of Econ \&Business Admin, Ferdowsi University of Mashhad, Iran.

Pathirawasam, C. (2013). Internal Factors Which Determine Financial Performance of Firms: With Special Reference To Ownership Concentration. Faculty of Commerce and Management Studies, University of Kelaniya, Sri Lanka.

Pathirawasam, C., \& Wickremasinghe, G. (2012). Ownership Concentration and Financial Performance the Case of Srilankan Listed Companies. Corporate Ownership \& Control, 9(4).

Pirvutoiu, I., \& Popescu, A. (2007). Analysis of Net Working Capital - A Basic Tool in Business Financing. Lucrari Stiintifce, Seriai, XI(3).

Prasetyantoko, \& Parmono, R. (2008). Determinants of Corporate Performance of Listed Companies in Indonesia. Atma Jaya Catholic University, Jakarta, Indonesia

Rahmawati, R., \& Hosen, M. N. (2012, April), Efficiency of Fund Management of Sharia Banking in Indonesia (Based On Parametric Approach). International Journal of Academic Research in Economics and Management Sciences, 1(2).

Ramasamy, B., Ong, D., \& Yeung, M. C. H. ( 2005). Firm Size, Ownership and Performance in the Malaysian Palm Oil Industry. Asian Academy of Management Journal of Accounting and Finance, 1, 81-104.

Sakunasingha, B. (June, 2006), An Empirical Study into Factors Influencing the use of value - Based Management Tools. Degree of doctor of business at administration, College of Management, Southern Cross University, Australia.

Sekaran, U. (2003). Research Methods for Business (4th ed.).

Septika, S. T. (2010). Semantic Change and Meaning Shift Analysis on Filmmaking Terms. English Department, Faculty of Humanities, Diponegoro University.

Shakoor, F., Khan, A. Q., \& Nawab, S. (2012). The Inter-Linkages of Working Capital, and Profitability in Pakistan (2001-2010). Academic Research International, 3(2). 


\section{MInstitute Machk $_{\text {Int }}$}

International Journal of Accounting and Financial Reporting ISSN 2162-3082

Soekhoe, S. G. (2012). The Effects of Working Capital Management on the Profitability of Dutch listed firms. Master thesis of Business Administration, School of Management And Governance, University of Twente, and Enschede, Netherlands.

Suhardjanto, D., Sulistyorini, E. J., \& Hartoko, S. (2009, December). The Influence of Fiscal Decentralization on the Public Expenditure in Indonesia. Journal Siasat Bisnis, 3(3), 233-252.

Taiwo, A. M. (2012). An Empirical Analysis of Capital Structure on Firms Performance in Nigeria, International Journal of Advances in Management and Economics. Retrieved from www.managementjournal.info

Vanitha, S., \& Selvam, M. (2007). Financial Performance of Indian Manufacturing Companies during pre and post-Merger. International Research Journal of Finance and Economics.

Vijayakumar, A. (2011). Cash Conversion Cycle and Corporate Profitability - An Empirical Enquiry in Indian Automobile Firms. International Journal of Research in Commerce, It \& Management, 1(2).

Zikmund, W. G. (2000). Business Research Methods (6th ed.). Harcourt College Publisher, Fort Worth, Texas.

\section{Appendix}

Table 1. Raw data of the study from 1999 to 2008

\begin{tabular}{lllllllllll}
\hline Company & year & ROA & CR & QR & NWC & ITR & ARTR & SGAER & CZ & CG \\
\hline ACC & 1999 & 8.3 & 1.4 & 1 & 7.5 & 0.9 & 4 & 17.3 & 7.8 & 34 \\
\hline AECPM & 1999 & 7.2 & 3 & 1 & 6.8 & 0.8 & 3.4 & 20 & 5.9 & 31 \\
\hline LCT & 1999 & 8 & 2 & 1.3 & 7.6 & 0.6 & 0.1 & 2 & 5.6 & 27 \\
\hline TNCMF & 1999 & 8.3 & 3 & 3 & 8.1 & 3.7 & 3.3 & 4.8 & 8.1 & 26 \\
\hline AECC & 1999 & 7.7 & 3 & 2 & 7.5 & 0.5 & 1 & 19.7 & 7.2 & 23 \\
\hline AECP & 1999 & 7.8 & 5 & 2.4 & 7.6 & 0.2 & 1 & 91.1 & 6.8 & 21 \\
\hline AECEI & 1999 & 8.1 & 2.3 & 1.3 & 7.3 & 2.6 & 0.1 & 17.1 & 7.2 & 4 \\
\hline AECERVOR & 1999 & 6.7 & 2.4 & 1 & 6.6 & 0.9 & 9 & 11 & 6.4 & 13 \\
\hline ACC & 2000 & 8.4 & 1.1 & 0.6 & 7.2 & 0.9 & 4 & 17.4 & 7.8 & 35 \\
\hline
\end{tabular}




\begin{tabular}{|c|c|c|c|c|c|c|c|c|c|c|}
\hline AECPM & 2000 & 7.2 & 2 & 0.5 & 6.9 & 0.7 & 3 & 0.8 & 6.9 & 32 \\
\hline LCT & 2000 & 7.9 & 2 & 2 & 7.6 & 0.9 & 2.5 & 6 & 7.4 & 28 \\
\hline TNCMF & 2000 & 8.4 & 3 & 2.4 & 8.1 & 3.3 & 3 & 11.7 & 8.1 & 27 \\
\hline AECC & 2000 & 7.8 & 3 & 2 & 7.5 & 0.6 & 1 & 16.3 & 7.2 & 24 \\
\hline AECP & 2000 & 7.8 & 5 & 2 & 7.6 & 0.2 & 1 & 68.3 & 6.9 & 22 \\
\hline AECEI & 2000 & 8.1 & 5 & 3 & 7.5 & 4.2 & 0.4 & 42.4 & 6.8 & 5 \\
\hline AECERVOR & 2000 & 6.9 & 2.3 & 1.2 & 6.7 & 0.6 & 10 & 7 & 6.4 & 14 \\
\hline $\mathrm{ACC}$ & 2001 & 8.4 & 8.4 & 1 & 7.6 & 1 & 2.1 & 18.4 & 7.8 & 36 \\
\hline AECPM & 2001 & 7.2 & 7.2 & 0.5 & 6.8 & 0.7 & 4 & 1.1 & 6.8 & 33 \\
\hline LCT & 2001 & 7.9 & 7.9 & 1.4 & 7.6 & 0.7 & 0.4 & 47 & 6.6 & 29 \\
\hline TNCMF & 2001 & 8.4 & 8.4 & 3 & 8.1 & 3.9 & 2.5 & 8.6 & 8.1 & 28 \\
\hline AECC & 2001 & 7.7 & 7.7 & 2.3 & 7.5 & 0.7 & 1.2 & 21.8 & 7.1 & 25 \\
\hline $\mathrm{AECP}$ & 2001 & 7.8 & 7.8 & 1.3 & 7.5 & 0.2 & 0.3 & 187.1 & 6.2 & 23 \\
\hline AECEI & 2001 & 8.1 & 8.1 & 1.6 & 7.4 & 1.4 & 0.2 & 62.4 & 6.6 & 6 \\
\hline AECERVOR & 2001 & 6.7 & 6.7 & 1 & 6.7 & 1.5 & 8 & 2 & 7.1 & 15 \\
\hline $\mathrm{ACC}$ & 2002 & 8.4 & 1.4 & 1 & 7.6 & 1 & 2.6 & 13.7 & 7.9 & 37 \\
\hline AECPM & 2002 & 7.1 & 3 & 1 & 6.8 & 0.8 & 5 & 1.2 & 6.8 & 34 \\
\hline LCT & 2002 & 7.8 & 2.4 & 1.4 & 7.6 & 0.3 & 1.5 & 34 & 7.2 & 30 \\
\hline TNCMF & 2002 & 8.3 & 2.4 & 2 & 7.9 & 2 & 1.5 & 8.2 & 7.9 & 29 \\
\hline AECC & 2002 & 7.6 & 3 & 2 & 7.4 & 0.7 & 1.2 & 24.1 & 7.1 & 26 \\
\hline $\mathrm{AECP}$ & 2002 & 7.8 & 4 & 1.5 & 7.5 & 0.2 & 0.1 & 197.8 & 5.8 & 24 \\
\hline AECEI & 2002 & 8 & 3 & 2 & 7.4 & 1.9 & 0.5 & 27.8 & 6.9 & 7 \\
\hline AECERVOR & 2002 & 6.7 & 1.2 & 1 & 6.6 & 0.4 & 6 & 8 & 6.4 & 16 \\
\hline $\mathrm{ACC}$ & 2003 & 8.4 & 1.3 & 1 & 7.5 & 1.1 & 3 & 11.3 & 7.9 & 38 \\
\hline AECPM & 2003 & 7.1 & 3 & 1.3 & 6.9 & 1.2 & 3 & 2.2 & 6.9 & 35 \\
\hline LCT & 2003 & 7.8 & 2.4 & 2 & 7.6 & 0.4 & 2 & 15 & 7.4 & 31 \\
\hline
\end{tabular}




\begin{tabular}{|c|c|c|c|c|c|c|c|c|c|c|}
\hline TNCMF & 2003 & 8.3 & 2 & 1 & 7.9 & 5.9 & 5 & 2.6 & 8.2 & 30 \\
\hline AECC & 2003 & 7.6 & 3.5 & 2 & 7.4 & 0.1 & 1.3 & 12.4 & 7.2 & 27 \\
\hline AECP & 2003 & 7.8 & 3 & 1 & 7.4 & 0.2 & 0.1 & 116 & 5.6 & 25 \\
\hline AECEI & 2003 & 8 & 3.6 & 2 & 7.6 & 0.3 & 0.3 & 67.3 & 6.8 & 8 \\
\hline AECERVOR & 2003 & 7 & 1.7 & 1.5 & 7 & 2.2 & 7 & 6 & 6.8 & 17 \\
\hline ACC & 2004 & 8.5 & 1.1 & 0.6 & 7 & 1.2 & 3.4 & 9.1 & 8 & 39 \\
\hline AECPM & 2004 & 7.1 & 4 & 2 & 7 & 1.7 & 2.2 & 0.6 & 7.1 & 36 \\
\hline LCT & 2004 & 7.8 & 2.2 & 1.4 & 7.6 & 0.6 & 1 & 21 & 7.3 & 32 \\
\hline TNCMF & 2004 & 8.4 & 2 & 1 & 7.9 & 3.4 & 5 & 2.6 & 8.4 & 31 \\
\hline AECC & 2004 & 7.7 & 6 & 3 & 7.5 & 0.6 & 1 & 12.1 & 5.7 & 28 \\
\hline $\mathrm{AECP}$ & 2004 & 7.7 & 3 & 1 & 7.4 & 0.2 & 0.1 & 183.5 & 7.9 & 26 \\
\hline AECEI & 2004 & 7.9 & 1.5 & 1 & 7.2 & 0.4 & 0.4 & 37.8 & 6.7 & 9 \\
\hline AECERVOR & 2004 & 7.1 & 3.7 & 2 & 7 & 7.7 & 6.5 & 1 & 7.3 & 18 \\
\hline $\mathrm{ACC}$ & 2005 & 8.9 & 1.6 & 0.6 & 8.1 & 1.4 & 5 & 9 & 8.1 & 40 \\
\hline AECPM & 2005 & 7.1 & 5 & 2 & 7 & 1.8 & 2.4 & 0.8 & 7.1 & 37 \\
\hline LCT & 2005 & 7.9 & 2 & 1.4 & 7.6 & 0.6 & 5 & 5.2 & 7.7 & 33 \\
\hline TNCMF & 2005 & 8.3 & 3 & 1 & 7.9 & 2.6 & 4 & 3.4 & 8.3 & 32 \\
\hline AECC & 2005 & 7.7 & 6 & 3 & 7.6 & 1.1 & 3 & 8.7 & 7.4 & 29 \\
\hline AECP & 2005 & 7.7 & 3.4 & 1 & 7.4 & 0.2 & 0.5 & 108.1 & 6.5 & 27 \\
\hline AECEI & 2005 & 7.6 & 1 & 1 & 6.6 & 0.5 & 0.5 & 23.1 & 6.9 & 10 \\
\hline AECERVOR & 2005 & 7.1 & 3.7 & 2 & 7 & 7.7 & 6.5 & 2 & 7.2 & 19 \\
\hline $\mathrm{ACC}$ & 2006 & 8.9 & 2 & 1.5 & 8.3 & 1.3 & 7.2 & 8 & 8.3 & 41 \\
\hline AECPM & 2006 & 7.1 & 7 & 3.5 & 7 & 1.3 & 2 & 0.5 & 7 & 38 \\
\hline LCT & 2006 & 8 & 2 & 1.5 & 7.7 & 0.5 & 8 & 5.2 & 7.9 & 34 \\
\hline TNCMF & 2006 & 8.3 & 3 & 1.5 & 7.9 & 3 & 7 & 7.9 & 8.3 & 33 \\
\hline AECC & 2006 & 7.7 & 3.5 & 1 & 7.3 & 1.3 & 7 & 15.8 & 7.6 & 30 \\
\hline
\end{tabular}




\begin{tabular}{lllllllllll}
\hline AECP & 2006 & 7.8 & 3 & 1 & 7.4 & 0.2 & 0.4 & 86.6 & 7.8 & 28 \\
\hline AECEI & 2006 & 7.7 & 1 & 1 & 6.7 & 0.3 & 0.3 & 66.6 & 6.3 & 11 \\
\hline AECERVOR & 2006 & 7.1 & 4.3 & 2 & 7 & 8.2 & 6 & 19 & 6.2 & 20 \\
\hline ACC & 2007 & 9 & 2 & 1.6 & 8.5 & 1.3 & 10 & 10 & 8.2 & 42 \\
\hline AECPM & 2007 & 7.4 & 3 & 2 & 7 & 0.6 & 1.4 & 0.7 & 6.8 & 39 \\
\hline LCT & 2007 & 8 & 2 & 1.3 & 7.7 & 0.3 & 2 & 2.2 & 7.6 & 35 \\
\hline TNCMF & 2007 & 8.7 & 3.3 & 2 & 8.3 & 3.8 & 5.5 & 3.2 & 8.6 & 34 \\
\hline AECC & 2007 & 8 & 4 & 2.6 & 7.6 & 3.4 & 3 & 16.9 & 7.9 & 31 \\
\hline AECP & 2007 & 7.8 & 2 & 1 & 7.2 & 0.1 & 0.4 & 110 & 6.2 & 29 \\
\hline AECEI & 2007 & 7.9 & 2.5 & 1.5 & 7.6 & 0.1 & 2.2 & 18 & 7.1 & 12 \\
\hline AECERVOR & 2007 & 7.2 & 5 & 1.3 & 6.6 & 2.8 & 8 & 4 & 6.8 & 21 \\
\hline ACC & 2008 & 9 & 1.4 & 1.1 & 8.1 & 1.4 & 10 & 10 & 8.3 & 43 \\
\hline AECPM & 2008 & 7.5 & 2 & 1 & 6.7 & 1.7 & 2.5 & 0.3 & 7 & 40 \\
\hline LCT & 2008 & 8.1 & 3 & 2 & 7.8 & 3.6 & 10 & 4.3 & 8 & 36 \\
\hline TNCMF & 2008 & 8.7 & 6 & 4 & 8.4 & 3.7 & 8 & 2.7 & 8.7 & 35 \\
\hline AECC & 2008 & 8 & 4 & 3 & 7.7 & 3.3 & 1.4 & 11.5 & 7.7 & 32 \\
\hline AECP & 2008 & 7.9 & 2 & 0.5 & 7.1 & 0.2 & 0.5 & 152.3 & 6.4 & 30 \\
\hline AECEI & 2008 & 7.7 & 2 & 1 & 7.4 & 1.8 & 5.1 & 7.7 & 7.8 & 13 \\
\hline AECERVOR & 2008 & 7.3 & 1.1 & 2 & 6.6 & 2.2 & 9 & 6 & 7.1 & 22 \\
\hline
\end{tabular}

Source: Researcher Design

\section{Copyright Disclaimer}

Copyright for this article is retained by the author(s), with first publication rights granted to the journal.

This is an open-access article distributed under the terms and conditions of the Creative Commons Attribution license (http://creativecommons.org/licenses/by/4.0/) 